\title{
BUDAYA DISIPLIN KERJA \\ Sebuah Sketsa Kerja Orang-Orang Jepang
}

\author{
Oleh Syafiah Sukaimi dan Muh. Said HM
}

Abstrak: Jepang, termasuk salah satunya negara di dunia yang turut diperhitungkan dalam persaingan dunia global atas berbagai percepatan kemajuan yang di alaminya terutama di bidang sain dan teknologi. Salah satu penyebab utamanya karena eksis dan lestarinya budaya disiplin di kalangan masyarakat Jepang pada umumnya. Sikap-sikap mental dan perilaku sosial positif setiap pribadi dalam berbagai aktivitas, merupakan wujud budaya disiplin mereka. Terlestarinya budaya disiplin mereka di samping karena faktor warisan tradisi leluhur mereka, serta berperannya secara aktif setiap orang tua dan para pendidik (guru) dalam mendidik generasinya hingga usia dianggap bisa mandiri, dan juga karena faktor dukungan pemerintah (Raja) dengan berbagai sarana dan fasilitas berasis teknologi modern.

Kata kunci: Sketsa, Budaya Disiplin Kerja, Orang-orang Jepang 


\section{BUDAYA DISIPLIN KERJA \\ Sebuah Sketsa Kerja Orang-Orang Jepang}

Oleh Syafiah Sukaimi dan Muh. Said HM

\section{Pendahuluan}

Negara Jepang hingga hari ini, tetap dominasinya sebagai salah satunya Negara di kawasan Asia yang sangat populer disebut sebagai "Negara Macan Asia". Sejak kejatuhan dan kehancurannya pada tahun 1945 hingga memasuki awal abad ke 21 ini yang disertai dengan musibah dahsyat sekalipun, yang namanya musibah tsunami pada tanggal 11 Maret 2011, mampu membuktikan kebangkitan kembali seiring dengan pesatnya kemajuan dan perkembangan penguasaan di bidang sains dan teknologi, serta penguasaan di bidang industri dan ekonomi. Percepatan kemampuan penguasaan berbagai bidang tersebut, Negara Jepang menyebabkan termasuk salah satunya Negara di dunia yang sangat diperhitungkan dalam percaturan skala Internasional oleh berbagai Negara-negara maju di siantearo dunia, termasuk misalnya dalam hal ini Amerika Serikat, China, Rusia dan Jerman.

Pesatnya kemajuan, perkembangan sains dan teknologi, serta industri dan ekonomi di Jepang, harus diakui bahwa salah satu sebab di antaranya yang sangat menentukan percepatan kemajuan tersebut disebabkan karena peran-peran aktif dan kontribusi Sumber Daya Manusia (SDM) yang dimiliki. Secara fenomenal sosial tampak sikap-sikap mental dan perilaku-perilaku sosial keseharian sangat kental dengan budaya disiplin yang mengagumkan. Sangat familiar sebagai masyarakat dan bangsa dengan budaya disiplin yang luar biasa dan tingkat produktivitas yang tinggi bila dibandingkan dengan berbagai Negara lainnya di dunia termasuk dalam hal ini Negara Indonesia sekalipun, pada hal di kalangan 
masyarakat Jepang mayoritas atau $70 \%$ tidak taat beragama, bahkan merasa bangga kalau dikatakan mereka tidak beragama. ${ }^{1}$ Menurut William K.Tabb, ternyata dengan pertimbangan aspek budaya tersebut menggambarkan harga masyarakat Jepang telah membayar untuk pembangunan ekonomi yang pesat, tidak ada yang bisa menyangkal bahwa pengaturan sosial dan budaya orang-orang Jepang memiliki banyak kaitannya dengan pembentukan dan pengembangan manufaktur Jepang dan yang hubungan kerja. Dengan kata lain, menurut deskripsi Tabb ini, bahwa orang-orang Jepang pada umumnya membutuhkan kerangka kerja yang menghubungkan budaya sosial tersebut dengan variabel ekonomi. ${ }^{2}$

Disiplin perilaku sosial, kepatuhan dan ketaatan pada berbagai aturan-aturan sosial, serta pemanfaatan interval batas waktu dengan sebaik-baiknya dalam berbagai aktivitas merupakan sesuatu yang sangat menjadikan perhatian utama oleh berbagai kalangan masyarakat Jepang, baik dari kalangan para pekerja atau tenaga kerja pada umumnya, akademisi, birokrasi maupun dari kalangan pengusaha-pengusaha industri di berbagai perusahaan pada umumnya. Oleh sebab itu, dapat dibenarkan kalau dikatakan bahwa ternyata budaya disiplin masyarakat Jepang dalam

${ }^{1}$ Mereka yang mayoritas tidak beragama, budaya disiplin dan etos kerja merupakan prinsip prilaku sosial sebagai perwujudan dari prinsip moral sosial yang diperoleh dari warisan nenek moyang mereka, dimana raja dianggap sebagai dewa yang harus ditaati. Di samping itu karena pengaruh kondisi sosial dimasanya dengan musibah kemiskinan, serta karena peran setiap orang tua dalam mendidik anak-anak mereka sejak usia dini, dan peran lembaga pendidikan setempat. Bagi mereka yang beragama sebagai simbol sosial belaka dan minoritas (Shintoisme dan Buddhisme), disamping sebagai prinsip moral sosial yang diperoleh sebagaimana disebutkan di atas, juga karena pengaruh simbolis dari pada ajaran-ajaran agama yang dianutinya. Sosiolog Robert Bellah mengatakan bahwa orang Jepang punya etos Bushido (etos para samurai = the way of the samurai) merupakan karakter dasar budaya kerja mereka. Etos Bushido adalah memutuskan secara benar dengan sikap benar, berani dan kesatria, murah hati dan mencintai, bersikap baik, santun dan hormat, bertindak adil, bersikap setulus-tulusnya, tanpa pamrih, menjaga kehormatan, martabat dan kemuliaan; mengabdi dan loyal. Manajemen Jepang yang berintikan "kaizen" (proses perbaikan ikremental yang berkesinambungan) memang hanya mungkin berhasil jika didukung etos kerja seperti itu. Baca, Etos Kunci Keberhasilan Bangsa dan Korporasi, (diakses Senin 7 Juli 2017, pukul 14.08), p. 1

${ }^{2}$ William K.Tabb, The Postwar Japanese System, Culture, Economic Transformation, Published: New York Oxford University Press, 1995, p. 151, 157 dan 289, 296 
berbagai aktivitas dan profesi, sudah menjadi suatu tradisi sosial yang wujudnya sebagai "budaya perilaku sosial" di kalangan mereka. Karenanya menurut Nakamura (Guru besar bidang politik pada Nihon University Jepang) bahwa sesungguhnya masalah budaya disiplin masyarakat Jepang, oleh setiap Negara-negara di belahan dunia bahkan oleh setiap manusia sekalipun akan senantiasa mau mempelajarinya, mungkin dengan mudah untuk dapat memahaminya, akan tetapi tidak semudah yang dibayangkan untuk mewujudkannya sebagai budaya perilaku sosial dalam suatu kelompok masyarakat. $^{3}$

Budaya disiplin orang-orang Jepang, merupakan suatu gambaran kompleks yang mencakup pengetahuan, kepercayaan, moral, hukum, adat istiadat dan kemampuan-kemampuan mereka serta kebiasaan-kebiasaan atau pola-pola perikelakuan yang membentuk struktur sosial dari masyarakat. Secara berturun-temurun dari generasi ke generasi tetap hidup terus, berkembang meskipun orang yang menjadi anggota masyarakat senantiasa silih berganti disebabkan oleh kematian dan kelahiran. ${ }^{4}$ Dengan kata lain, bahwa perilaku-perilaku sosial sebagai wujud dari budaya disiplin masyarakat Jepang, akan senantiasa eksis dan terlestari, terwarisi dari generasi ke generasi selanjutnya dalam konsep moral yang ditanamkan dengan secara ketat terutama melalui warisan tradisional nenek moyang mereka, disamping melalui jalur pendidikan, yang dimulai dari peran-peran aktif setiap orang tua dalam mendidik anak-anak mereka sejak di usia dini, hingga terbentuk karakter pribadipribadi yang mampu mandiri menjelang memasuki usia dewasa dan seterusnya. $^{5}$

Berdasarkan hal tersebut, maka dalam tulisan berikut ini diketengahkan sketsa berbagai perilaku sosial (sikap mental) dan prinsip moral yang menyebabkan eksis dan terlestarinya budaya disiplin orangorang Jepang.

${ }^{3}$ Baca, Muh. Said HM, dkk, Budaya Disiplin dan Etos Kerja Tenaga Kerja di Jepang, Pekanbaru: LP2M UIN Suska Riau, 2014, p. 38 dst.

${ }^{4}$ Soerjono Soekanto, Sosiologi Suatu Pengantar, edisi 5, Jakarta: CV. Rajawali, 1985, p. 166-167

${ }^{5}$ Muh. Said HM, dkk, Op.cit 


\section{Pengertian Budaya dan Disiplin}

Sebutan budaya dan disiplin merupakan dua rangkaian kata yang saling mempengaruhi dalam kehidupan sosial masyarakat suatu bangsa, dengan maksud pengertian masing-masing kedua istilah atau sebutan tersebut adalah sebagai berikut :

Budaya dalam kata sangsekertanya adalah buddhayah merupakan bentuk jamak dari kata "buddhi" yang berarti budi atau akal. Dalam artian, bahwa hal-hal yang bersangkutan atau berubungan dengan budi atau akal disebut dengan budaya. Wujud budaya (kebudayaan) adalah segala sesuatu yang terdapat di dalam masyarakat ditentukan adanya oleh kebudayaaan yang dimiliki oleh masyarakat itu sendiri. Zidi Gazalba mendefinisikan kebudayaan adalah cara hidup, cara berlaku-berbuat dalam tiap segi kehidupan masyarakat. Cara hidup terwujud melalui penanaman kebiasaan. Kebiasaan membentuk kebudayaan ialah setelah ia diwariskan dari generasi ke generasi berikutnya, atau dari angkatan demi angkatan selanjunya. ${ }^{6}$ Sedangkan menurut EB. Tylor (antropolog 1871) bahwa kebudayaan adalah kompleks yang mencakup pengetahuan, kepercayaan, kesenian, moral, hukum, adat istiadat dan lain kemampuankemampuan serta kebiasaan-kebiasaan yang didapatkan oleh manusia sebagai anggota masyarakat. ${ }^{7}$

Dengan demikian, terindikasi bahwa kebudayaan mencakup kesemuanya yang didapatkan atau dipelajari oleh manusia sebagai anggota masyarakat, atau segala sesuatu yang dipelajari dari pola-pola perikelakuan yang normatif, yaitu mencakup segala cara-cara atau polapola berfikir, merasakan dan bertindak, yang oleh Herskovits memandang kebudayaan sebagai sesuatu yang superorganic karena kebudayaan yang berturun temurun dari generasi ke generasi tetap hidup terus, terlestari

${ }^{6}$ Soerjono Soekanto, Sosiologi Suatu Pengantar, edisi 5, Jakarta: PT. Rajawali Press, 1985, p. 165, dan Sidi Gazalba, Antropologi Budaya Gaya Baru, Jilid 2, Jakarta: Agus Salim, tt, p. 248

${ }^{7}$ Ibid. 
meskipun orang-orang yang menjadi anggota masyarakat senantiasa silih berganti disebabkan kematian dan kelahiran. ${ }^{8}$

Sedangkan disiplin berasal dari kata latin desiplina berarti latihan atau pendidikan kesopanan dan kerohanian serta pengembangan tabiat. Dalam Kamus Bahasa Indonesia, disiplin mengandung pengertian latihan batin dan watak dengan maksud supaya segala perbuatannya selalu mentaati tata tertib. Maksudnya selalu patuh kepada peraturan-peraturan yang telah ditetapkan, atau patuh pada aturan yang ketat, dengan kata lain tata tertib yang harus dipatuhi. ${ }^{9}$ Disiplin adalah kesadaran dan kesediaan seseorang mentaati semua peraturan-peraturan dan normanorma sosial yang berlaku dalam melaksanakan suatu kegiatan. Atau ketaatan kepada lembaga atau organisasi beserta apa yang menjadi ketentuan yang berdasarkan keinsyafan dan kesadaran bahwa tanpa adanya ketaatan segala apa yang menjadi tujuan organisasi (perusahaan) tidak akan menjadi tercapai. ${ }^{10}$ Menurut Eko Jalu Santoso, bahwa disiplin adalah sikap mental untuk melakukan hal-hal yang seharusnya pada saat yang tepat dan benar-benar menghargai waktu. ${ }^{11}$

Jadi, pada hakikatnya disiplin merupakan pembatasan kebebasan dari pekerja (workers), oleh karena itu dalam usaha menegakkan disiplin

\footnotetext{
${ }^{8}$ Ibid, p. 167
}

${ }^{9}$ Peter Salim, dkk, Kamus Bahasa Indonesia Kontemporer, edisi 1, Jakarta: Modern English Press, 1991, p. 359, dan bandingkan T. Deli MB, dk, Kamus Bahasa Indonesia, Bandung: Citra Umbara, 1997, p. 175. Disiplin mempunyai tiga aspek, yaiktu : 1). Sikap mental yang merupakan sikap taat dan tertib sebagai hasil dan pengembangan dan latihan, pengendalian pikia dan pengendalian watak, 2). Pemahaman yang baik mengenai sistem aturan perilaku, norma criteria dan standar sedemikian rupa, sehingga pemehaman tersebut menumbuhkan pengertian yang dalam atau kesadaran, bahwa ketaatan atau aturan, norma criteria dan standar merpakan syarat mutlak untuk mencapai keberhaslan, dan 3). Sikap dan kelakuan secara wajar menunjukkan kesungguhan hati untuk mentaati segala hal secara cermat dan tertib. Baca, Soegeng Prijodarminto, Disiplin Kiat menuju Sukses, Jakarta: Pradya Paramita, 1994, p. 23

${ }^{10}$ Malayu S.P. Hasibuan, Manajemen Sumber Daya Manusia, edisi 4, Jakarta : PT. Bumi Aksara, 2001, p. 193, dan Mr. Prayudi Admosudirjo, Administrasi dan Manajemen Umum, Jakarta: PT. Ghalia Indonesia, 1982, p. 28

${ }^{11}$ Eko Jalu Santoso, Good Ethos, 7 Etos Kerja Terbaik dan Mulia, edisi 1, Jakarta: PT. Gramedia, 2012, p. 219 
bukan hanya sekedar untuk berdisiplin saja, akan tetapi disiplin juga harus dapat menunjang daripada tujuan yang ingin dicapai oleh suatu organisasi atau suatu kelompok usaha tertentu. Dengan demikian, disiplin merupakan suatu kondisi yang tercipta dan terbentuk melalui proses dari serangkaian prilaku yang menunjukkan nilai-nilai ketaatan, kepatuhan, kesetiaan dan atau ketertiban. Atau sebagai suatu sikap, tingkah laku dan perbuatan seseorang (pekerja) yang sesuai dengan peraturan dari suatu organisasi (instansi/perusahaan) baik yang tertulis maupun yang tidak tertulis. Meliputi misalnya: kepatuhan karyawan (pekerja) pada jam-jam kerja, kepatuhan pada perintah atau instruksi dari pimpinan, serta taat pada peraturan dan tata tertib yang berlaku, berpakaian seragam ketempat kerja atau pengenal instansi, penggunaan dan memelihara alat-alat perlengkapan kantor dengan hati-hati, serta bekerja dengan mengikuti cara-cara pekerja yang telah ditentukan oleh instansi. $^{12}$

Atas dasar pengertian tersebut di atas, dapat dipahami bahwa substansi budaya disiplin merupakan fenomena perilaku sosial manusia dalam melakukan berbagai aktivitas, senantiasa mengacu dan sesuai dengan aturan-aturan hukum yang berlaku, diwujudkan secara terus menerus atas dasar penuh rasa kesadaran diri dan rasa tanggungjawab yang tinggi. Oleh karena itu, budaya disiplin yang mantap pada hakikatnya akan tumbuh dan akan selalu terpancar dari hasil kesadaran manusia itu sendiri. Budaya disiplin yang tidak bersumber dari hati nurani manusia akan menghasilkan disiplin temporer, yang lemah dan tidak akan bisa bertahan lama dan lestari, disiplin tidak akan hidup melainkan akan mati. Tetapi sebaliknya, budaya disiplin yang tumbuh atas dasar kesadaran yang tinggi dari setiap pribadi dalam suatu kelompok masyarakat, akan ada jaminan bisa bertahan lama dan

${ }^{12}$ Fred N. Kerlinger, dk, Korelasi dan Analisis Regresi Berganda, Yogyakarta: BPFE, 1984, p. 21. Upaya yang harus dilakukan dalam proses pelaksanaan disipliner, antara lain melalui pendekatan (1). Aturan tungku panas, yakni membakar dengan segera, memberi peringatan, memberi hukuman yang konsisten dan membakar tanpa membeda-bedakan (2).Tindakan disipliner progresif, dan (3).Tindakan disipliner tanpa hukuman, baca, Henry Simamora, Manajemen Sumberdaya Manusia, Yogyakarta : STIE YKPN, 1989, p. 315 
berkesinambungan, menjadi wujud prilaku sosial terwarisi dari generasi ke generasi selanjutnya.

Substansi budaya disiplin seperti dimaksudkan di atas sejalan dengan realitas sosial dalam wujud perilaku sosial setiap pribadi orang-orang Jepang pada umumnya. Aturan-aturan sosial yang diberlakukan secara ketat sekalipun dengan mudah ditaati, dan seolah-olah tercipta dengan sendirinya. Tampak dalam prilaku sosial setiap pribadi dengan penuh kesadaran dan ketaatan, dengan budaya tertib mentaati aturan-aturan dalam berlalu lintas misalnya, tertib di jalan-jalan raya, tertib keluar masuk dalam kreta listrik dan tertib keluar masuk dalam bus-bus umum, serta tertib berjalan-jalan di berbagai tempat-tempat keramaian sekalipun. Suasana lingkungan bersih di berbagai areal tercipta rasa keindahan dan serba nyaman, sejuk dan damai, karena setiap pribadi senantiasa memperhatikan betapa pentingnya menjaga kebersihan dan keindahan lingkungan, dan ditambah dengan perhatian dan dukungan penuh dari pemerintah dengan mengadakan (memberikan) berbagai sarana dan fasilitas.

Dimana-mana tempat yang dianggap sangat strategis, pembuangan tempat-tempat atau kantong-kantong pembuangan sampah diadakan dan diatur sedemikian rapih. Saluran-saluran pelarian air tak kalah hujan turun deras berfungsi dengan baik, sehingga kebanjiran dapat tertanggulangi secara efektif, dan jalan-jalan rayapun tampak bersih dan berseri, senantiasa bebas dari kemacetan dan antrian kendaraan. Demikian pula halnya di berbagai tempat kelompok-kelompok atau komunitas kerjasama dalam suatu usaha tertentu, terutama para workers (tenaga kerja) memanfaatkan waktu-waktu kerja dengan sebaik-baiknya. Setiap pekerja benar-benar bekerja secara efektif, prinsip tepat waktu masuk kerja, saat bekerja dan pulang kerja merupakan kegiatan rutinitas melekat pada setiap pribadi pekerja. ${ }^{13}$

\section{Sketsa Negara dan Bangsa Jepang}

Jepang, merupakan salah satu Negara di kawasan Asia yang berbentuk kepulauan, yang dinamakan oleh orang Jepang sendiri adalah

\footnotetext{
${ }^{13}$ Muh. Said H, dkk, Loc. cit
} 
Nihon dan Nippon, yang mempunyai arti atau julukan sebagai Negara asal Matahari atau Matahari Terbit dan Negeri Sakura. Jepang yang beribukota di Tokyo dengan luas wilayah 378.000 kilometer persegi, merupakan salah satu Negara Industri yang pesat perkembangannya, terbesar ke-2 setelah Amerika Serikat.

Letak Geografis: Kepulauan Jepang terdiri dari empat pulau utama dan lebih 6.000 pulau yang kecil, dan sekitar 1.500 gunung berapi. Letaknya di kawasan Asia timur yang terpisah dari benua Asia, di sebelah timur benua Asia dan sebelah barat Samudera Pasifik. Letak astronomis: 30 LU-47 LU dan 128 BT - 146 BT, dengan luas wilayah sekitar 234.890 mil persegi atau: 378.000 kilometer persegi. Batas-batas : Utara adalah Laut Okhstoks, Timur adalah Samudera Pasifik, Selatan adalah Laut Cina Timur dan Laut Filipina, serta Barat adalah laut Jepang dan Selat Korea. Bentang alam terdiri dari Pulau-pulau, empat pulau utama Jepang tersebut, yaitu : Hokkaido, Honshu, Shikoku dan Kyushu. Pada umumnya adalah daerah bergunung-gunung yang titik tertingginya adalah Gunung Fuji atau Fujiyama (3778 M). Pegunungan di Jepang merupakan masih termasuk rangkaian pegunungan Sirkum Pasifik, sehingga banyak ditemukan gunung apinya. Sungai di Jepang pendek-pendek serta deras sehingg baik untuk pembangkit tenaga listrik, Danau di Jepang kecil-kecil dan yang terbesar adalah Danau Biwa. ${ }^{14}$

Jepang termasuk Induk bangsa Mongoloid, suku bangsa aslinya adalah suku bangsa Aino yang tinggal di Pulau Hokkaido. Penduduk Jepang yang terpadat adalah di Pulau Honsu dan bagian utara Pulau Khyushu. Keadaan penduduk Jepang ditandai penurunan tingkat kelahiran secara terus menerus dan peningkatan harapan hidup makin menua (harapan hidup tertinggi di dunia). Penurunan tingkat fertilitas juga menyebabkan turunnya jumlah penduduk.

Menurut Sensus Penduduk dalam tahun 2005, populasi penduduk Jepang mengalami penurunan untuk pertama kalinya sejak Perang Dunia menjadi 127.770.000 orang. Sedangkan menurut perkiraan Biro Statistik Jepang, penduduk Jepang pada 1 Desember 2009 berjumlah 127.530.000

\footnotetext{
${ }^{14}$ Baca, Letak Geografis Negara Jepang, (diakses: Senin 7 Juli 2017, pukul 14.08)
} 
orang, terdiri dari 62.130.000 laki-laki dan 65.410.000 perempuan, dan dibandingkan populasi pada Desember 2008 terjadi penurunan sebesar 0,12\% (sekitar 150 orang). Kemudian penduduk usia 65 tahun ke atas di Jepang, sejak 1 Oktober 2000 meningkat dari 22.005.152 orang menjadi 25.672.005 orang (1 Oktober 2005), dan hingga pada 1 Desember 2009 meningkat lagi menjadi 29.100 .000 orang. Sensus Januari 1997 meprediksi 27,4 \% populasi Jepang akan berusia di atas 65 tahun pada tahun 2025, dan akan bertambah menjadi 32,3\% pada tahun 2050. Sementara persentase penduduk usia muda (0-14 tahun) terus menyusut, sehingga pada tahun 2008 berjumlah 17.180 .000 orang (13,5\%). Demikian halnya populasi usia produktif (15-64 tahun) terus mengalami penurunan sejak tahun 1996 sebesar 64,5\% (82.300.000 orang). Kemudian sampai pada 1 Juli 2009, persentase penduduk 0-14 tahun dan 15-64 tahun juga mengalami penurunan, masing-masing sebesar 0,84\% (145.000 orang) dan 1,02\% (844.000 orang) dibandingkan data 1 Juli $2008 .^{15}$

Bahasa bangsa Jepang dengan huruf Kanji dan sementara agama yang dianutnya sebagian besar tidak beragama (70 \%) dan selebihnya minoritas adalah agama Shinto dan agama Budha. ${ }^{16}$ Masyarakat Jepang pada

${ }^{15}$ Ibid, p. 2, dan bandingkan, Demografi Jepang, p. 1 (diakses: Senin 7 Juli 2014, pukul 14.08)

${ }^{16}$ Kitab-kitab yang dipakai sebagai pedoman para penganut agama Shinto dan tidak dipandang sebagai kitab-kitab suci ialah Kojiki (berisi cerita-cerita dan naluri kuno), Nihongi (berisi cerita-cerita Jepang), dan Yengishiki (berisi nyanyian-nyanyian dan pujaan). Bangsa Jepang berkeyakinan bahwa raja-raja zaman dahulu berasal dari keturunan dewa-dewa, oleh karena itu raja-raja Jepang sangat dihormati. Api dianggap suci, sebagai lambang kesucian dewa-dewa, dipelihara oleh suku nakomi (suku mulia dan berkuasa). Jiwa dianggap suci, memaksa seseorang untuk mengakui kesalahan-kesalahan, orang yang bersalah harus menghukum dirinya sendiri. Kebersihan diri, tiap orang harus memelihara diriya dari segala kotoran supaya tetap bersih, sebab dewa-dewa tidak mau menghampiri orang yang berjiwa kotor. Memelihara pergaulan, orang-orang jahat jangan didekati, sebab kejahatan itu timbul dari jiwa yang jahat pula. Kerusakan jiwa itu ialah karena hantu dan syaithan melalui suara yang jahat, karena itu orang harus berusaha agar jiwanya jangan sampai dimasuki setan dan jauh dari perkataan-perkataan yang keji dan kotor, dan setiap orang harus tulus dan berbudi luhur, dan jika ia mati dimasukkan kedalam golongan kami atau roh-roh yang baik. Baca, Abu Achmadi, Perbandingan Agama, Jilid 2, Sala: AB. Sitti Syamsiyah, 1975, p. 6-7 
umumnya tidak peduli pada agama, kalaupun dia mempercayai agama tertentu (shinto atau budha), pada umumnya dia tidak suka memamerkan agama tersebut, agama yang dianutinya hanya sebatas simbol sosial semata. Tidak ikut campur urusan pribadi orang lain, dan masalah agama dianggapnya sebagai urusan pribadi. Pemerintah sekalipun tidak boleh ikut campur dalam urusan agama, dilarang keras memakai anggaran negara untuk hal-hal agama. Semua lembaga agama tidak boleh diberi hak istimewa dari pemerintah (negara), dan tidak boleh melaksanakan kekuatan politik, negara dan instansinya tidak boleh melakukan kegiatan agama dan pendidikan agama tertentu. Dengan demikian, etika sosial masyarakat Jepang tidak didasari atas ajaran-ajaran agama, melainkan dalam hal ini atas dasar etika demi komunitas. Etika sosial masyarakat Jepang, tujuan utamanya tiada lain upaya membentuk hubungan baik di dalam komunitas. ${ }^{17}$

Adapun sebutan Shinto (bagi yang bergama shinto) adalah istilah kontemporer untuk sistem dewa dan keyakinan tentang hubungan antara manusia, lingkungan alam dan negara. Shinto mengajarkan bahwa Jepang adalah unik tanah para dewa. Agama tidak memiliki dogma resmi atau kitab suci. Selama sebagian besar sejarah Jepang, Shinto dan Budha telah hidup berdampingan dan saling mempengaruhi satu sama lain. Shinto terkait erat dengan keluarga kekaisaran dan idiologi nasionalis. Sementara Budha mengajarkan bahwa "keselamatan tersedia hanya untuk sebuah terpilih sedikit, orang-orang yang berusaha untuk mencapai pencerahan dan praktek pekerjaan baik, yang akan meningkatkan kemampuan seseorang untuk mengatasi jerat kehidupan fana. Melalui pengabdian yang tepat siapa pun bisa berharap untuk keselamatan sementara, selama hidup mereka di bumi, tetap menjadi bagian dari dunia fana".

Dari sisi sosial budaya bangsa Jepang banyak menerima pengaruh dari cina, tetapi terdapat perbedaan yang jelas antara keduanya, seperti seni sendra tari, upacara minu the, tehnik merangkai bunga dan lain sebagainya. Tapi kebudayaan bangsa Jepang yang harus dicontoh adalah

${ }^{17}$ Muh. Said HM, dkk, Loc.cit, dan bandingkan dalam Etos Kerja Jepang Mendunia, (diakses: Sabtu 20 September 2017 pukul 19.25. 
suka bekerja keras dan disiplin yang tinggi. Adapun bentuk pemerintahannya adalah dalam bentuk Kekaisaran yang menganut parlementer, Kepala negaranya adalah Kaisar/Tenno, dan Kepala pemerinahannya adalah Perdana Menteri. ${ }^{18}$

Kemudian dari sudut ekonomi, Jepang merupakan salah satu negara yang paling maju di dunia. GDP (Produk domestik bruto, yaitu nilai semua barang dan jasa yang dihasilkan di Jepang dalam setahun) adalah peringkat kedua tertinggi di dunia, setelah Amerika Serikat. Ekonominya sangat efisien dan mampu bersaing dalam area yang berhubungan ke perdagangan Internasional, meskipun memiliki sumber daya alam yang rendah. Kegiatan di bidang ekonomi meliputi ; bidang Industri, Pertanian, Perikanan, Pertambangan, Perhubungan dan Perdagangan.

Di bidang Industri, misalnya: bidang otomotif, elektronik, komputer, semikonduktor, besi dan baja, petrokimia, farmasi, bioindustri, galangan kapal, dirgantara, tekstil, serta (makanan yang diproses Industri Manufaktur Jepang banyak bergantung pada impor bahan mentah dan bahan bakar minyak) adalah salah satu kekuatan Jepang. Pola umum yang dijalankannya dimana perusahaan-perusahaan Jepang mengimpor bahanbahan mentah, lalu mengolah dan membuatnya sebagai barang jadi yang dijual di dalam negeri atau di ekspor. Khususnya di bidang Perobotan (teknologi robot), teknologi Jepang memimpin dunia. ASIMO, robot humanoid (berbentuk seperti manusia) dikembangkan oleh Honda, dapat berjalan dengan dua kaki dan berbicara bahasa manusia. Dalam waktu dekat, robot ini akan aktif dalam berbagai bidang dan mungkin hidup berdampingan dengan manusia, seperti dalam film-film fiksi sains.

Di bidang pertanian, meskipun hanya $12 \%$ dari luas daratan di Jepang yang bisa digunakan untuk pertanian, namun hasilnya memuaskan karena ditunjang oleh lahan yang subur (mengandung abu vulkanis), di samping penggarapan lahan dilakukan secara intensif dengan didukung teknologi maju. Hasil-hasil pertanian Jepang berupa ; padi, kentang, jagung, gandum, kacang, kedelai dan teh. Hasil peternakan berupa ; babi, ayam, telur, sapi dan susu. Sayur-sayuran berupa ; lobak,

${ }^{18}$ Letak Geografis ..., Op.cit, p. 2 
kubis, ketimun, tomat, wortel, bayam dan selada. Sedangkan buahbuahan yang banyak ditanam adalah apel dan jeruk. Apel meupakan produk unggulan Tohoku dan Hokkaido, dan buah pir merupakan produk pertanian unggulan Prefektur Tottori. Perkebunan jeruk berada di Shikoku, Shizuoka dan Kyushu.

Di bidang perikanan, Jepang mempunyai sumber laut yang melimpah. Ikan merupakan bagian utama dari makanan sehari-hari di Jepang, dan industri perikanan Jepang sangat aktif, sejak tahun 1989 menempati urutan ke-2 di dunia setelah Cina dalam tonase penangkapan ikan. Dan 7 tahun kemudian (1996), Jepang berada diperingkat ke-6 dalam total tangkapan ikan di bawah Cina, Peru, Amerika Serikat, Indonesia dan Chili. Jepang juga menebarkan kontroversi dengan mendukung perburuan ikan paus. Di antara hasil laut yang diambil misalnya ; sarden, cakalang, kepiting, udang, salem, cumi-cumi, kerang, tuna saury, yellowtail dan makeret.

Di bidang transportasi, juga sangat berkembang di Jepang. Jaringanjaringan jalan dan rel kereta api mencakup hampir setiap bagian wilayah Jepang, bersama dengan layanan angkutan udara dan laut yang luas. Shinkansen (kereta listrik super cepat - kecepatan tinggi yang paling aman di dunia) berjalan dengan kecepatan maksimal 250-300 km per jam. Jaringan Shinkansen mempnyai lima rute yang menyebar dari Tokyo dan Osaka. Di samping itu, Jepang juga mempunyai jaringan jalur kareta reguler dan jaringan jalur subway (kereta bawah ranah) terbaik di dunia dan terus berkembang. Beraneka macam kereta Jepang termasyhur karena keberhasilannya dan ketepatan waktunya. Kemudian, sektor jasa merupakan tiga perempat dari total penghasilan ekonomi Jepang. Industri utama sektor jasa di Jepang berupa bank, asuransi realestat, bisnis eceran, transportasi dan telekomunikasi. Mitsubishi UFJ, Mizuho, NTT, TEPCO, Nomura, Mitsubishi Estate,Tokio Marine, Japan Railway, Seven \& I, dan Japan Airlines adalah nama-nama perusahaan Jepang yang termasuk perusahaan terbesar dunia. Ada sekitar 326 perusahaan Jepang 
berada dalam daftar Forbes Global 2000, atau 16,3\% dari total perusahaan dalam daftar Forbes Global 2000 pada tahun 2006. ${ }^{19}$

Khususnya misalnya dalam kerjasama hubungan Internasional Negara Jepang dengan Negara Republik Indonesia, meliputi: di bidang politik, masing-masing kedua negara saling menempatkan duta besarnya, bidang ekonomi, terutama perdagangan, ekspor ke Jepang antara lain minyak bumi mentah, gas alam cair, aluminium, bijih besi, timah. Sedangkan inpor Indonesia yaitu mesin-mesin kendaraan bermotor, mesin industri, peralatan elektronika, lembaran besi baja, kapal dan bahan-bahan kimia. Sedangkan bidang Teknologi, Jepang membantu dalam pembangunan bendungan Asahan, pembangunan pabrik aluminium dan pembangunan kilang minyak palju. Demikian halnya di bidang pendidikan dan kebudayaan, masing-masing kedua negara saling tukar menukar pelajar dan Mahasiswa. ${ }^{20}$

\section{Eksis dan Terlestarinya Budaya Disiplin}

Sebagaimana dipahami bahwa budaya disiplin masyarakat Jepang pada umumnya, senantiasa terwarisi dari generasi ke generasi selanjutnya dalam konsep moral yang ditanamkan melalui warisan tradisional nenek moyang mereka, dengan keyakinan mereka bahwa raja-raja Jepang sejak zaman dahulu sampai sekarang berasal dari keturunan dewa-dewa. Oleh karena itu, raja-raja Jepang sangat dihormati dan sangat ditaatinya. ${ }^{21}$ Timbulnya silsilah keturunan raja-raja Jepang menurut keyakinan masyarakat Jepang dalam cerita kitab Kojiki dan Nihongi, bahwa mulamula bumi dan langit serta seisinya dijadikan oleh para dewa. Dua di antaranya dewa-dewa itu turun dari langit akan menjadikan bumi Jepang. Dua dewa tersebut ialah Isanagi-no-kami (laki-laki) dan Isanami-no-kami (perempuan). Kedua dewa inilah kemudian menurunkan beberapa dewa, termasuk juga dewa Matahari yang bernama Amaterasu-omi-kami. Dewa langit ini kemudian mengirim seorang dewa ke bumi bernama Ninigo-nomikoto yang kemudian bercucu bernama Jimmi Tenno raja Jepang yang

${ }^{19}$ Baca, Ekonomi Jepang, p. $1-4$ (diakses, Senin 7 Juli 2017, pukul 14.10), dan bandingkan Ekonomi dan Industri, p. 1-2 (diakses, Senin 7 Juli 2017, pukul 14.13)

${ }^{20}$ Letak Geografis Negara Jepang..., Loc. cit, p. 3

${ }^{21}$ Ibid. 
pertamakali. Itulah sebabnya, maka nama resmi Jepang ialah Tenno yang artinya "raja langit". Jimmi Tenno naik takhta kerajaan pada tahun 660 SM, dan dia itulah yang menurunkan raja-raja Jepang sampai sekarang ini. Tenno raja Jepang itu keturunan Dewa Surya. Amaterasu-Omi-Kami sangat dipercayai dan sangat ditaatinya, patuh pada raja, memuja alam dan roh. Demikian pula bendera kebangsaan Jepang berbentuk tanda Matahari, untuk menunjukkan bahwa negaranya tercipta dari Matahari, tempat kediaman Dewa Surya Amaterasu. ${ }^{22}$

Di samping hal tersebut di atas, yang juga senantiasa diperhatikan adalah penanaman prinsip-prinsip moral dengan ketat dalam berperilaku sosial melalui peran-peran aktif orang tua dan guru melalui jalur pendidikan. Oleh sebab itu, peran serta orang tua dan guru di Jepang dalam meningkatkan kualitas pendidikan tidak dapat dikesampingkan. Orang tua berperan aktif dalam memberikan motivasi dan inovasi, bimbingan dan didikan-didikan sejak anak usia dini hingga menjelang usia 20 tahun. Misalnya sejak kecil menjelang usia TK hingga tamat SMP senantiasa dibimbing dan ditanamkan nilai-nilai moral dan prilaku sosial yang baik serta kemandirian secara ketat, sehingga hingga setelah tamat SMA, anak-anak mereka sudah bisa mandiri, dengan usaha sendiri mampu membiayai keperluan segala kebutuhan selama kuliah di Perguruan Tingga hingga meraih kesarjanaan.Demikian pula sebaliknya, misalnya peran guru-guru di sekolah, sepulang sekolah, murid-murid diharuskan membersihkan ruang kelas, toilet dan lingkungan sekolah selama 20-30 menit, baru diperbolehkan pulang. Guru-guru secara terbuka menerima kritik dan saran dalam proses pendidikan yang sifatnya membangun demi kemajuan pendidikan. Bagi masyarakat Jepang hubungan orang tua dengan guru dianggap suatu hal yang sangat penting dalam proses pendidikan, maka di setiap sekolah-sekolah diadakan suatu wadah sebagai sarana komunikasi yang diberi nama Komite Sekolah, yang oleh pemerintah Jepang sendiri dibentuk sejak tahun $1952 .{ }^{23}$

${ }^{22}$ Ibid.

${ }^{23}$ Ibid, dan bandingkan dalam artikel harian Kompas, Senin 22 September 2014, p. 26 dengan tajuk Berbagi Budaya Bersih ala Jepang, serta dalam Etos Kerja Masyarakat Jepang, Loc.cit, p. 3 
Sedemikian pentingnya pendidikan bagi masyarakat Jepang, maka pasca perang dunia II, kebijaksanaan pendidikan nasional Jepang mengalami berbagai perubahan-perubahan; struktur, kurikulum, buku teks, serta aspek lain yang terkait dengan unsur memajukan bangsa, dijalaninya. Ternyata dengan berbagai perubahan kebijaksanaan tersebut telah berhasil mensejajarkan Jepang dengan negara-negara sekutu yang pernah mengalahkannya, bahkan dalam beberapa hal, Jepang mampu mengungguli mereka. Pembangunan watak, karakter dan pendidikan moral harus menopang pendidikan ilmu pengetahuan dan teknologi. Oleh sebab itu, tradisi di Jepang yang berkembang hingga dewasa ini adalah dalam satu tahun ajaran sekolah, dialokasikan waktu beberapa hari bagi siswa untuk berkunjung ke pusat-pusat kebudayaan, sebagai bagian dari pendidikan charakter building (watak).

Ada semacam konsensus bahwa sekolah-sekolah di Jepang berkewajiban mengajarkan nilai-nilai budaya sebagai fondasi sikap, moral dan kebiasaan hidup. Dengan kebijaksanaan dan perbaikan mutu pendidikan yang senantiasa dilakukan, menyebabkan hingga hari ini, ternyata berhasil membuat ekonominya sangat kuat, literasi penduduknya sangat tinggi, pemerintahan demokrasinya stabil, masyarakat sangat fungsional, infrastrukturnya sangat handal dengan berbasis teknologi tinggi, dan angka kekerasan dan kejahatannya cukup relatif kecil.

Keberhasilan bangsa Jepang mengangkat negerinya unggul dalam percaturan dunia Internasional dalam berbagai bidang, karena tidak terlepas dari keistimewaan pendidikan di Jepang; bangsa Jepang sebagai bangsa yang education minded; senantiasa punya keyakinan bahwa sukses dalam pendidikan formal sama dengan sukses dalam kehidupan, atau sebagai satu-satunya jalan untuk mengejar status ekonomi dan sosial. Keberhasilan pendidikan sebagai akibat dari usaha bersama orang tua, siswa dan guru. Selama 9 tahun pendidikan dasar mendapat pelajaran; membaca, menulis, berhitung, sains, musik dan seni, yang sangat tinggi mutunya dan berproporsi seimbang dalam kurikulum.

Sistem pendidikan di Jepang dicirikan oleh pemberian motivasi yang tinggi kepada siswa untuk berhasil, kebiasaan mengajar yang efektif, pemanfaatan waktu belajar yang produktif, lingkungan belajar yang 
kondusif, memperhatikan perkembangan watak, dan layanan penyediaan lapangan kerja secara koordinatif bagi lulusan SMA maupun Perguruan Tinggi, dan di samping itu yang sangat terstimewa kerena dilengkapi dengan berbagai sarana yang lengkap dan serba pasilitas modern berbasis teknologi canggih. ${ }^{24}$

Selanjutnya, adapun berbagai prinsip-prinsip moral yang senantiasa di junjung tingggi oleh masyarakat Jepang dalam beraktifitas, atau dalam melakukan pekerjaan pada berbagai lapangan pekerjaan, sehingga budaya disiplin dan etos kerja mereka terlestari, menjadikan negara Jepang salah satu negara di kawasan Asia bahkan di dunia sekalipun, memiliki percepatan tingkat ekonomi kuat dan turut diperhitungkan, antara lain di antaranya sebagai berikut: ${ }^{25}$

1. Prinsip Moral Bushido ala Samurai, merupakan semangat yang betul-betul tertanam dan fenomenal dalam diri setiap pribadi masyarakat Jepang, yakni prinsip moral yang mengangkat kode etik kepahlawanan ala militer kaum samurai. Dimaknai sebagai prinsip moral atau sikap rela mati demi negara atau kerajaan dan kaisar. Memberikan semangat pantang menyerah dan berusaha

${ }^{24}$ Tiap-tiap sekolah di Jepang wajib memberi pelajaran sekurang-kurangnya 240 hari setahun atau rata-rata 6 hari seminggu selama 40 pekan. Tahun pelajaran di Jepang jauh lebih lama namun persentase siswa yang masuk sekolah jauh lebih tinggi. Orang tua siswa berpendiria bahwa anak-anak mereka harus masuk sekolah walauapapun yang terjadi. Mungkin tidak akan didapati mereka merancang bepergian dengan seluruh keluarga apabila sekolah tidak libur. Di samping itu juga, pada umumnya ayah mereka bekerja 6 hari dalam sepekan, maka tidak ada kesempatan bagi keluarga bertamasyah. Mereka boleh tidak masuk sekolah apabila sakit. Tetapi banyak pula anak-anak yang walapun sakit enggan tinggal di rumah, tetap sekolah. Tahun pelajaran sekolah di Jepang di mulai bulan April berakhir pada bulan Maret. Libur pendek beberapa kali, dua pecan pada akhir tahun pelajaran, pekan "emas" sesudah tahun pelajaran baru berjalan sebulan, atau setengah bulan libur musm panas, sepekan pada bulan oktober, dan dua pekan menjelang perayaan tahun baru. Masa libur yang pendek-pendek itu memberi istirahat pada siswa sekolah, tetapi tidak cukup lama untuk membuat mereka lupa akan kedudukannya sebagai murid. Bahkan waktu libur musim panas ada kalanya mereka diberi tugas atau pergi berdarmawisata yang diselenggarakan oleh sekolah. Baca, Etos Kerja Masyarakat Jepang, Op.cit, p. 3-4, dan Muh. Said HM, dkk, loc.cit

${ }^{25}$ Baca, artikel dalam Belajar dari Disiplin Kerja Bangsa Jepang, Loc.cit, p. 1 dst, dan Etos Kerja Orang Jepang, Loc.cit, p. 1 dst. 
keras dalam pencapaian tujuan, meskipun memerlukan pengorbanan jiwa sekalipun dengan cara harakiri atau bunuh diri. Hal tersebut dilakukan semata-mata karena ingin memperlihatkan usaha mereka untuk menebus diri yang hilang akibat kalah dalam bersaing atau kalah dalam pertarungan (perang). Dengan semangat prinsip moral samurai, menciptakan bangsa Jepang menjadi bangsa yang tak mudah menyerah karena sumber daya alamnya yang minim misalnya, juga tak menyerah pada berbagai bencana alam yang senantiasa dialaminya, terutama gempa dan tsunami. Persaingan bisnis antara perusahaan sejenis misalnya, bukanlah menjadi hambatan bagi mereka, melainkan sebagai tantangan untuk lebih kreatif, inovatif dalam penciptaan produkproduk lebih modern, menyebabkan mereka unggul dalam meraih harga pasar.

2. Prinsip Moral Keishan (Kaizen), yang berpandangan bahwa dalam hidup ini hendaknya selalu fokus pada upaya perbaikan secara terus menerus, perubahan-perubahan yang terjadi dalam budaya kerja harus senantiasa dilakukkan upaya perbaikannya dengan cara selalu kreatif, inovatif dan produktif, menuntut kerajinan, ketekunan, kesungguhan, minat dan keyakinan, sehingga akhirnya timbul kemauan untuk selalu belajar dari orang lain. Artinya, merupakan prinsip moral yang selalu mendorong bangsa Jepang memiliki komitmen tinggi pada pekerjaan dan kinerja. Setiap pekerjaan perlu dilaksanakan dan diselesaikan sesuai dengan jadwal (tepat waktu) agar tidak menimbulkan pemborosan, sehingga akan menghasilkan produk-produk yang berkualitas tinggi.

3. Prinsip Moral Kerja Keras. Bangsa Jepang sangat terkenal sebagai pekerja keras. Oleh sebab itu, ukuran nilai dan status orang Jepang sangat di dasarkan pada disiplin kerja dan jumlah waktu yang dihabiskan di tempat dimana mereka bekerja. ${ }^{26}$ Kecintaan orang Jepang pada pekerjaannya, membuat mereka fokus pada pekerjaannya. Tanpa pengawasan pun mereka bekerja dengan

${ }^{26}$ Baca, Etos Kerja Orang Jepang, Op.cit, p. 1 
baik, penuh dedikasi dan disiplin. Ketika jam 8 pagi masuk kerja, mereka langsung bekerja sesuai dengan tugas masing-masing, dan bila tiba masa istirahat, mereka betul-betul istirahat sambil makan siang, dan bila akhir pekerjaan tiba, kadang-kadang mereka terlambat pulang, karena pulang cepat menurut mereka adalah sesuatu yang agak memalukan, menandakan bahwa karyawan (tenaga kerja) tersebut sudah tidak dibutuhkan lagi oleh perusahaan.

4. Prinsip Moral Hidup Hemat, Loyal dan Inovasi. Bangsa Jepang pada umumnya memiliki semangat hidup serba hemat dalam keseharian, dan sebaliknya seolah-olah anti sikap-sikap konsumerisme berlebihan dalam berbagai bidang kehidupan. Sikap kesederhaan dalam fenomena dan fakta sosial lebih dominan, meskipun sesungguhnya terhadap apa saja yang bisa mejadi tuntutan kebutuhan hidup mereka bisa saja diupayakan. Misalnya, mayoritas lebih mementingkan berjalan kaki di jalanjalan raya, dan pergi pulang dari melakukan berbagai beraktivitas, demikian pula dengan naik sepeda, ketimbang memakai kendaraan mobil pribadi. Kemudian dengan sikap-sikap loyalitas mereka membuat sistem karir mereka dalam suatu kelompok usaha tertentu atau perusahaan berjalan dan tertata dengan rapi, serta fokus, tidak suka yang namanya berpindah-pindah pekerjaan. Dalam bekerja benar-benar penuh dedikasi dan rasa tanggung jawab, berbagai kepentingan dan kebutuhan pelanggan dilayaninya dengan sebaik-baiknya, dan sesegera mungkin dipenuhinya, karena bagi berbagai dunia usaha atau perusahaan di Jepang, langganan (konsumer) adalah dewa bagi mereka. Implikasi sikap-sikap loyalitas mereka dalam bekerja, menyebabkan bangsa Jepang, terkenal juga sebagai bangsa yang mempunyai kelebihan dalam meracik temuan orang dan kemudian memasarkannya dalam bentuk yang diminati oleh masyarakat. Misalnya teknik perakitan kendaraan roda empat yang bukan produksi Jepang, patennya dimiliki oleh orang Amerika, tetapi ternyata orang Jepang dengan prinsip moral inovasinya, bisa mengembangkan industri perakitan kendaraan 
yang lebih cepat dan murah serta handal dalam dunia pemasarannya”.

Bila diamati sikap-sikap mental dan perilaku sosial masyarakat Jepang pada umumnya, secara faktual dan realitas sosial dapat dibenarkan kalau dikatakan bahwa sesungguhnya budaya disiplin mereka pada umumnya dapat dipahami secara mendasar dari berbagai fakta perilaku sosial tersebut, adalah sebagai berikut:

Pertama, Disiplin dalam Pemanfaatan Waktu. Salah satu indikator budaya disiplin kerja, karena ketaatan pada berbagai aturan yang diberlakukan, terutama dalam hal pemanfaatan waktu dengan sebaikbaiknya dalam bekerja. Dengan pemanfaatan waktu dengan sebaikbaiknya dalam bekerja, senantiasa tepat waktu dan disiplin dalam bekerja, maka akan sangat mempengaruhi sekaligus menentukan tingkat produktivitas pekerja dan kualitas kinerja sebagaimana yang diharapkan. Menurut Fredrich Winslow Taylor (1856-1915), salah seorang pakar dibidang ilmu manajemen (bapak manajemen berdasarkan ilmu) dalam salah satu hasil penelitiannya yang dinamakan time and motion studies atau studi mengenai penetapan standar kerja yang didasarkan pada perhitungan waktu. Hasil penelitian tersebut, berangkat dari suatu kenyataan yang dialaminya disaat ia bekerja dan memimpin sebuah perusahaan di Midvale Steel Company di Philadelpia, bahwa ternyata para pekerja di perusahaan rata-rata mereka bekerja dibawah standar dari apa yang sebenarnya mampu mereka kerjakan. Oleh kerena itu, menurut Taylor bahwa untuk mencapai tujuan sebuah perusahaan, misalnya meningkatkan profif perusahaan, maka tingkat produktivitas perlu ditingkatkan. Produktivitas dapat diukur dari tingkat output dan prestasi kerja. Produktivitas yang baik tercapai manakala prestasi kerja yang dihasilkan oleh pekerja dapat menghasilkan output produk sesuai dengan yang ditargetkan, baik dari jumlah maupun dari segi kualitas yang memenuhi standar produk yang telah ditetapkan. ${ }^{27}$

${ }^{27}$ Ernie Tisnawati Sule, dk, Pengantar Manajemen, edisi 1, Jakarta : Prenada Media, 2005, p. 30, bandingkan Malayu SP. Hasibuan, Manajemen Dasar, Pengertian dan Masalah, edisi 9, Jakarta : CV. Haji Masagung, 1993, p. 7-8 
Budaya seperti ini, dalam artian perhitungan penggunaan dan pemanfaatan waktu dengan sebaik-baiknya dalam bekerja, pada umumnya ada pada sikap mental dan perilaku sosial kalangan para tenaga kerja dalam setiap kelompok-kelompok usaha tertentu di Jepang. Disiplin waktu dalam bekerja, ketepatan waktu mulai jam masuk hingga jam pulang kerja, demikian pula memanfaatkan waktu ketika waktu-waktu istirahat. Makanya salah satu prinsip moral mereka dalam bekerja adalah "kerja ya kerja, istirahat ya istirahat". Ketika misalnya jam 8 pagi masuk kerja, tak ada lagi obrolan dan candaan, mereka langsung bekerja ditempat tugas masing-masing, di komputer masing-masing, atau sibuk langsung di depan workstation masing-masing. Selanjutnya, ketika tiba saatnya waktu istirahat makan siang (hiru gohan no jikan), mereka serentak menghentikan aktivitas masing-masing sambil bercanda ria dengan sesama pekerja sambil menuju kantin (shokudo). ${ }^{28}$

Kedua, Motivasi dan Orientasi dalam Bekerja. Orang-orang Jepang dalam bekerja bermuara kepada motivasi setiap orang dalam bekerja, karena motivasi merupakan keadaan internal individu yang melahirkan kekuatan, kegairahan, keinginan dan dinamika, serta mengarahkan tingkah laku pada tujuan. ${ }^{29}$ Dalam berbagai teori motivasi, pada umumnya orang mau bekerja karena tuntutan pemenuhan berbagai kebutuhan, baik kebutuhan yang disadari maupun kebutuhan atau keinginan yang tidak disadari, demikian juga orang mau bekerja demi untuk mendapatkan kebutuhan fisik dan mental.

Menurut Peterson dan Plowman (psikolog) mengatakan bahwa pada umumnya setiap orang mau bekerja kerena disebabkan :

${ }^{28}$ Pada umumnya perusahaan-perusahan di Jepang, terutama kelompok-kelompok usaha kerja di bidang bangunan dan industri, dalam setiap minggunya bekerja mulai hari senin sampai hari Jum'at, dan setiap harinya para pekerja mulai masuk kerja jam 8 pagi sampai dengan waktu pulang kerja jam 17 sore, dengan klasifikasi waktu kerja yaitu: 1). Mulai kerja jam 8-10 dan istirahat 30 menit, 2). Kemudian lanjut kerja jam 10.30-13 dan istirahat 30 menit, dan seterusnya 3). Kerja jam 13.30- 17 sore/ istirahat pulang kerja. Baca, Muh. Said HM, dkk, Loc.cit

${ }^{29}$ Abdul Hamid Mursi, SDM Yang Produktif, Pendekatan Al-Qur'an dan Sains, edisi 4,, terjemahan Drs. Moh. Nurhakim, MA, Jakarta : Gema Insani Press, 1999, p. 91 
a. The desire to live, artinya keinginan untuk hidup merupakan keinginan utama dari setiap orang; manusia bekerja untuk dapat makan, dan makan untuk dapat melanjutkan hidupya.

b. The desire for posession,artinya keinginan untuk memiliki sesuatu merupakan keinginan manusia yang keduadan ii salah satu sebab mengapa manusia mau bekerja.

c. The desire for power, artinya keinginan akan kekuasaan merupakan keinginan selangkah di atas keinginan untuk memiliki; mendorong orang mau bekerja.

d. The desire for recognation, artinya keinginan akan pengakuan merupakan jenis terakhir dari kebutuhan dn juga mendorong orang untuk bekerja. ${ }^{30}$

Atas dasar tersebut, menurut Malayu SP. Hasibuan bahwa setiap pekerja dalam berbagai profesi mempunyai motif-motif tertentu dan mengharapkan berbagai kepuasan dari hasil pekerjaannya. Kebutuhankebutuhan yang dipuaskan dengan bekerja pada umumnya adalah: Kebutuhan fisik dan keamanan; menyangkut kepuasan kebutuhan fisik atau biologis seperti makan, minum, tempat tinggal dan semacamnya, di samping kebutuhan akan rasa aman dalam menikmatinya. Kebutuhan sosial; karena manusia tergantung satu sama lain, maka terdapat berbagai kebutuhan yang hanya bisa dpuaskan apabila masing-masing individu ditolong atau diakui oleh orang lain. Dan kebutuhan egoistik; ini berhubungan dengan keinginan orang untuk bebas, untuk mengerjakan sesuatu sendiri dan untuk puas karena berhasil menyelesaikannya. Kepuasan-kepuasan di atas ada yang dinikmati di luar pekerjaan, di sekitar pekerjaan, dan lewat pekerjaan. ${ }^{31}$

${ }^{30}$ Malayu SP. Hasibuan, Op.cit, p. 182-183, dan bandingkan teori yang diperkenalkan oleh seorang psikolog Abraham Maslow, bahwa orang-orang atau setiap individu termotivasi untuk berperilaku dalam pekerjaannya untuk memenuhi kebutuhannya yang teridiri dari lima tingkatan kebutuhan, yaitu physical needs, safety and security needs, social/belongingness needs sesteem needs, and self actualization needs. Baca, Ernie Trisnawati, dk, Op.cit, p. 240 dst.

${ }^{31}$ Ibid, p. 183 
Interpretasi para ahli tampak mengarah pada sisi yang menekankan pentingnya kelompok-kelompok kerja, kondisi sosial dan hubungan kerja untuk mengetahui sejauh mana individu dapat menerima pekerjaan dan tingkat produktivitasnya. Termasuk gaji atau upah juga mempunyai nilainilai ekonomi yang dapat diperoleh oleh setiap pekerja melalui pekerjaannya, dan dapat mempengaruhi pandangan-pendangan dan sikapnya terhadap pekerjaan. ${ }^{32}$

Berdasarkan sebagian hasil penelitian yang dikemukakan oleh C. Walker dan R. Guest, diketahui bahwa jenis pekerjaan bukan merupakan sumber utama perasaan cocok dalam bekerja, tetapi perasaan ini merupakan hasil kerjasama antar berbagai faktor, yakni faktor rekanrekan sesama pekerja, kesempatan untuk maju, status sosial, gaji atau upah, dan faktor kemantapan kerja. Motivator terkuat di perusahaanperusahaan adalah perasaan mantap dari sisi materi, berupa kesesuaian antara gaji atau upah dengan kebutuhan, beban hidup, tingkat pendidikan dan pengalaman. ${ }^{33}$

Sebagaimana diketahui bahwa dengan budaya disiplin masyarakat Jepang dalam hal bekerja, membentuk sikap dan mental kerja yang positif lagi produktif. Oleh karena itu, ukuran nilai dan status mereka didasarkan pada disiplin kerja dan jumlah waktu yang dihabiskan di tempat mereka bekerja (etos kerja). Kecintaan mereka pada pekerjaannya, membuat mereka fokus pada pekerjaannya, tanpa ada pengawas pun mereka bekerja dengan baik, penuh dedikasi dan disiplin. Mereka dengan tulus melakukan apa saja demi keberhasilan perusahaan tempat mereka bekerja, bahkan hebatnya mereka sanggup bekerja lembur tanpa mengharapkan bayaran tambahan.

Dengan demikian, orientasi mereka dalam bekerja bukan karena semata-mata termotivasi oleh jumlah gaji atau upah yang besar. Memang, besaran gaji atau upah merupakan hal yang diperhatikan, namun hal itu bukan menjadi suatu hal yang utama bagi mereka, yang penting mereka dalam bekerja bagaimana perusahaan bisa untung besar, sehingga mereka akan mendapatkan keuntungan juga. Dengan kata lain, orientasi mereka

\footnotetext{
${ }^{32}$ Abdul Hamid Mursi, Op.cit, p. 90

${ }^{33} \mathrm{Ibid}$,
} 
dalam bekerja dengan anggapan jika hasil produksi meningkat dan perusahaan mendapat keuntungan besar, secara otomatis mereka akan mendapatkan kompensasi setimpal. ${ }^{34}$

Ketiga, Kerjasama Kolektif dan Pelayanan Perusahaan. Kerjasama dalam upaya meraih berbagai tujuan adalah hal yang niscaya, karena tidak seorang pun dengan sendirinya bisa meraih berbagai kesuksesan dalam hal apa saja, tanpa melalui kontribusi orang lain di sekitarnya. Oleh karena itu, dengan melalui kerjasama yang baik akan ada jaminan mencapai tujuan yang diharapkan secara efektif dan efisien. Umumnya dalam dunia usaha, dalam proses kerjasama diatur melalui yang namanya aturan-aturan kontrak kerja. Dimaksudkan sebagai perjanjian kontrak antara pekerja dengan pihak manajemen perusahaan, di mana pekerja memberikan tenaganya atas suatu pekerjaan sesuai dengan keinginan pihak manajemen perusahaan, sehingga pantas bila kedua belah pihak mendapatkan manfaat, terutama yang diperbolehkan berupa kompensasi terhadap pekerja, baik untuk jangka waktu tertentu atau menyelesaikan pekerjaan tertentu.

Kontrak atau perjanjian kerja yang dibuat dan ditaati oleh masingmasing pihak, dipastikan akan dapat menciptakan suasana harmonisasi kerja, suatu ketenangan kerja, jaminan akan kepastian hak dan kewajiban, baik bagi pihak pekerja maupun pihak manajemen perusahaan. Bahkan sangat boleh jadi akan lebih mempengaruhi tingkat produktivitas akan semakin lebih meningkat, sehingga pihak manajemen (perusahaan) akan dapat mengembangkan dunia usahanya, dan lebih luas lagi dari itu, tentunya akan dapat memberikan peluang lapangan kerja baru bagi masyarakat pada umumnya.

Perusahaan-perusahaan di Jepang, menganggap bahwa kemampuan untuk bekerjasama adalah hal yang sangat penting. Bekerja secara kolektif lebih diutamakan dari pada individu. Dengan kata lain, budaya di Jepang tidak terlalu mengakomodir kerja-kerja yang terlalu bersifat individualistik, termasuk klaim hasil pekerjaan, biasanya ditujukan untuk tim atau kelompok. Musyawarah mufakat atau sering mereka sebut

\footnotetext{
${ }^{34}$ Baca; Belajar dari Disiplin Kerja Bangsa Jepang, Loc.cit, p. 2
} 
dengan "rin-gi" adalah ritual dalam kelompok, dalam artian bahwa berbagai keputusan strategis yang harus dilakukan harus dibicarakan dalam "rin-gi". ${ }^{35}$

Skill individu memang penting, tetapi yang lebih utama dari itu adalah kerjasama untuk mencapai tujuan. Kerjasama dalam team work membuat para tenaga kerja (karyawan) dengan mudah bisa saling melengkapi kekurangan masing-masing, karena dengan semangat bekerjasama, maka kemampuan individu bisa berkembang. Oleh pihak perusahaan sendiri menganggap setiap pekerja (karyawan) seperti investasi, yang harus senantiasa dididik mulai dari level pekerjaaan yang terendah, diberikan pelatihan-pelatihan dan sebagainya, diberikan kesempatan kepada setiap karyawan untuk mendayagunakan kemampuan dan pengalamannya, sehingga karyawan diharapkan dengan mudah mengerti akan berbagai tugas dan tanggungjawabnya, loyal dengan perusahaan, yang pada akhirnya bisa mengembangkan diri ketingkat produktivitas yang tinggi".

Selain dari itu, karyawan juga akan dapat memahami pentingnya tugas-tugas pelayanan terbaik terhadap publik, karena yang namanya para konsumen atau para pelanggan perusahaan adalah ibarat "dewa perusahaan", yang segala macam akan kebutuhannya harus segera dipenuhi dengan pelayanan yang terbaik, dan oleh pihak perusahaan sendiri juga harus senantiasa berusaha mewujudkan komunikasi atau hubungan yang langgeng dan berkesinambungan terhadap para langganannya. ${ }^{36}$ Dengan kata lain, jika perusahaan ingin selalu dianggap yang terbaik di mata pelanggannya, perusahaan harus memberikan pelayanan yang terbaik, memberikan pelayanan yang dapat memenuhi dan memuaskan pelanggan atau masyarakat, serta memberikan fokus pelayanan kepada pelanggan. Pelayanan dalam sektor publik dalam artian didasarkan pada aksioma bahwa "pelayanan adalah pemberdayaan".

\footnotetext{
${ }^{35}$ Baca, Etos Kerja Orang Jepang, Loc.cit, p. 3

${ }^{36}$ Baca, Inti Budaya Kerja Orang Jepang, Loc.cit, p. 2
} 


\section{Simpulan}

Memahami uraian-uraian yang telah dikemukakan di atas, maka bagi penulis selanjutnya berkesimpulkan sebagai berikut: Pertama, Negara Jepang termasuk salah satu negara yang tingkat percepatan kemajuan dan perkembangan penguasaan di bidang sains dan teknologi, serta industri dan ekonomi, hingga zaman now senantiasa tetap sangat diperhitungkan oleh berbagai negara di dunia dalam persaingan dunia global. Antara lain salah satu faktor yang menyebabkannya, karena orang-orang atau masyarakat Jepang pada umumnya kental dengan budaya disiplin yang tinggi dalam melakukan berbagai aktivitas.

Kedua, Eksis dan terlestarinya budaya disiplin kerja orang-orang Jepang, bukan karena semata-mata pengaruh dari nilai-nilai ajaran keberagamaan mereka, melainkan terutama bagi mereka yang tidak beragama sebagai wujud sikap-sikap mental dan prinsip-prisip moral warisan dari nenek moyang mereka, pemerintah atau sang Raja sebagai dewa, senantiasa penuh kesadaran ditaati dari berbagai aturan-aturan yang diberlakukan. Di samping itu, karena kontribusi dan peran serta setiap orang tua dan guru dalam meningkatkan kualitas pendidikan tidak dapat dikesampingkan, dan di sisi lain yang turut menentukan juga, karena didukung oleh berbagai sarana dan fasilitas serba modern berbasis teknologi tinggi.

Secara faktual dan fenomena sosial, budaya disiplin kerja orang-orang atau masyarakat Jepang pada umumnya dapat dipahami dari berbagai aspek kegiatan sosial dalam beraktivitas. 


\section{DAFTAR PUSTAKA}

Abu Achmadi, Perbandingan Agama, Jilid 1, Sala: AB. Sitti Syamsiyah, 1975

Abdul Hamid Mursi, SDM Yang Produktif Pendekatan Al-Qur'an $\mathcal{E}$ Sains, terjemahan Moh. Nurhakim, edisi 1, Jakarta: Gema Insani Press, 1997

Belajar dari Disiplin Kerja Bangsa Jepang (artikel diundu: Senin 24 Februari 2017, pukul 11.30 wib)

Demografi Jepang (artikel diundu: Rabu 5 Maret 2017, pukul 9.39)

Eko Jalu Santoso, Good Ethos, 7Etos Kerja Terbaik dan Mulia, edisi 1, Jakarta: PT. Gramedia, 2012

Etos: Kunci Keberhasilan Bangsa dan Korporasi (artikel diundu: Senin 7 Juli 2017 pukul 14.30)

Fred N.Kerlinger, dk, Korelasi dan Analisis Regresi Berganda,Yogyakarta: BPFE, 1984

Henry Simamora, Manajemen Sumberdaya Manusia Yogyakarta: STIE YKPN, 1989

Inti Budaya Kerja Orang Jepang (artikel diundu: Senin 24 Pebruari 2017 pukul 11.30)

Letak Geografis Negara Jepang (artikel diundu: Rabu 5 Maret 2017, pukul 9.30)

Malayu S.P. Hasibuan, Manajemen Sumber Daya Manusia, edisi 4, Jakarta: PT. Bumi Aksara, 2001

Muh. Said HM, dkk, Budaya Disiplin dan Etos Kerja Tenaga Kerja di Jepang, Pekanbaru: LP2M UIN Suska Riau, 2014

Mr. Prayudi Admosudirjo, Administrasi dan Manajemen Umum, Jakarta: Ghalia Indonesia, 1982

Sidi Gazalba, Antropologi Budaya Gaya Baru, Jilid 2, Jakarta: Agus Salim, tt. 
Soerjono Soekanto, Sosiologi Suatu Pengantar, edisi 5, Jakarta: CV. Rajawali, 1985

Kesadaran Hukum dan Kepatuhan Hukum, edisi 1, Jakarta: CV. Rajawali, 1982

Soegeng Prijodarminto, Disiplin Kiat Manuju Sukses, Jakarta: Pradya Paramita, 1994

Peter Salim, dkk, Kamus Bahasa Indoensia Kontemporer, edisi 1, Jakarta: Modern English Press, 1991

T. Deli MB, Kamus Bahasa Indonesia, Bandung: Citra Umbara, 1997

William K.Tabb, The Postwar Japanese System, Culture, Economic, Transformation, Published: New York Oxford Universty Press, 1995

Syafiah Sukaimi, MA adalah Dosen tetap pada Fakultas Tarbiyah dan Keguruan Universitas Islam Negeri Sultan Syarif Kasim Riau. Email : syafiah@gmail.com

Dr. H. Muh. Said HM, adalah Dekan pada Fakultas Ekonomi dan Ilmu Sosial Universitas Islam Negeri Sultan Syarif Kasim Riau. Email: muh.said@uin-suska.ac.id 